\title{
Effects of Varying Dietary Forage Particle Size in Two Concentrate Levels on Chewing Activity, Ruminal Mat Characteristics, and Passage in Dairy Cows ${ }^{1}$
}

\author{
Q. Zebeli, ${ }^{* 2}$ M. Tafaj, ${ }^{*}$ I. Weber, ${ }^{*}$ J. Dijkstra, $\dagger$ H. Steingass, ${ }^{*}$ and W. Drochner ${ }^{*}$ \\ *University of Hohenheim, Institute of Animal Nutrition (450), Emil-Wolff-Str. 10, D-70599 Stuttgart, Germany \\ †Animal Nutrition Group, Wageningen University, Marijkeweg 40, 6709 PG Wageningen, the Netherlands
}

\begin{abstract}
The objective of this study was to investigate the effects of varying dietary forage particle size on chewing activity, ruminal mat characteristics, passage, and in situ ruminal and total tract digestion in dairy cows at a low- and high- concentrate inclusion. The experiment was designed as a $4 \times 4$ Latin square with a $2 \times 2$ factorial arrangement of treatments. Four ruminally cannulated late-lactating dairy cows were restrictively fed (17 kg of dry matter/d), in four 23-d periods, 1 of 4 different diets varying in the theoretical particle size (6 and $30 \mathrm{~mm}$ ) of hay (56.6\% NDF of dry matter) and in the levels (approximately 20 and 60\%, dry matter basis) of a cereal-based concentrate. Ingredients of the ration were offered separately to the cows; dietary hay and low-level concentrate were offered twice daily at 0800 and $1600 \mathrm{~h}$, whereas concentrate of the high-level treatment was offered in 4 meals a day at 0800,1200 , 1600 , and $1900 \mathrm{~h}$. This study showed that altering the forage particle size from 6 to $30 \mathrm{~mm}$ in a low-concentrate diet significantly increased the rumination time and ruminal mat consistency without affecting ruminal fermentation and passage. Further, particle breakdown and proportion of mat in the rumen increased, and in situ hay dry matter degradability improved, which in turn indicated a higher capacity of ruminal digesta to degrade fiber. On the other hand, increasing the forage particle size in a diet containing a high amount of concentrate increased the proportion of dry matter retained on a 1.18-mm screen from 37.5 to $42.0 \%$ and extended the rumination time by $100 \mathrm{~min} / \mathrm{d}$, as well as increasing the ruminal mat consistency. However, ruminal particle breakdown, short-term ruminal $\mathrm{pH}$, fibrolytic capacity of the digesta, and proportion of mat
\end{abstract}

Received June 8, 2006.

Accepted December 30, 2006.

${ }^{1}$ Part of the results of this study were presented at the 59th Congress of the German Society for Nutrition Physiology, held in Stuttgart-Hohenheim, Germany.

${ }^{2}$ Corresponding author: zebeli@uni-hohenheim.de in the rumen decreased. This was also reflected in a higher bailable liquid pool, increased fractional passage rate of solid digesta from the reticulorumen, and increased retention time in the hindgut, which in turn indicated a shift of fiber digestion from the rumen to the lower digestive tract. This study showed that the response of chewing or ruminating activity alone seemed to be insufficient to assess the dietary physical effectiveness or fiber adequacy in limit-fed dairy cows when high-concentrate diets were fed separately. Based on the results of this study, we concluded that inclusion of coarsely chopped hay in the high-concentrate diet did not appear to further improve rumen conditions and digestion when the rations were formulated to exceed the fiber requirements in limit-fed dairy cows.

Key words: physical fiber, chewing activity, ruminal mat, dairy cow

\section{INTRODUCTION}

The challenge primarily met in high-yielding dairy cow feeding is to provide an energetically high-density ration without compromising the ruminal ecosystem, animal welfare, production, and reproductive performance. Dairy cows need dietary forage having an adequate particle size to enhance digesta stratification in the reticulorumen, and consequently chewing activity, ruminal buffering, and fiber degradation, as well as to prevent digestive disorders (NRC, 2001). Inadequate fiber levels negatively affect rumen digestion and may reduce the amount of energy that the ration provides (Yang and Beauchemin, 2006). Yet fiber adequacy can be difficult to predict from tables. Results obtained recently (Zebeli et al., 2006) strengthened the argument that accounting for dietary physically effective fiber is a more efficient procedure to assess fiber adequacy in dairy cows than simply taking into account the proportion of dietary fiber or forage fiber. However, because of a lack of sufficient characterization and a standardized, validated evaluation system, neither the NRC (2001) nor the Gesellschaft für Ernährungsphysiologie (GfE, 
2001) include recommendations for physical characteristics of the fiber in dairy cow diets.

Nevertheless, it should be noted that the current systems for evaluating the physical effectiveness of ruminant diets do not sufficiently consider the various effects of physical fiber on ruminal fermentation and rumen conditions, especially on the characteristics of digesta stratification (Mertens, 1997). Sutherland (1988) described the ruminal mat as a very effective first-stage separator. Through filtration and mechanical entanglement, the ruminal mat functions to retain potentially escapable fiber particles, thus increasing the time allowed for digestion (Welch, 1982; Weidner and Grant, 1994).

Numerous studies (e.g., Beauchemin et al., 2003; Kononoff and Heinrichs, 2003; Yang and Beauchemin, 2006) have been carried out over the last several years to investigate the effect of forage particle size on feed intake, chewing activity, ruminal digestive processes, and performance in high-producing dairy cows. However, the response obtained from these studies has been inconclusive. For example, dietary particle size was observed in some studies to be closely related to chewing activity and rumen $\mathrm{pH}$ (Beauchemin et al., 2003; Tafaj et al., 2005b) but in other studies it was poorly related to chewing time and $\mathrm{pH}$ (Yang et al., 2001; Kononoff and Heinrichs, 2003). The complexity of the interactions between feed intake, concentrate inclusion, degradation processes in the rumen, and animal performance often leads to difficulties in quantitative characterization of the effects of forage particle size. The quantitative integration of various factors that affect the efficacy of particle size to improve the rumen environment for fiber degradation require models based on the underlying mechanisms, and consequently appropriate data to advance understanding and improve predictions (Dijkstra et al., 2002).

There is evidence that rapidly digested carbohydrate sources, such as barley grain, increase the need for effective fiber in dairy cows (Beauchemin and Rode, 1997), indicating an interaction between ruminal fermentability and particle size of the diet. In addition, this fact suggests that the response to dietary particle size in dairy cows may be different with a low compared with a high inclusion of concentrate. However, under conditions of ad libitum intake, it is often difficult to quantify the effects of particle size, also because the increased DMI would still result in an increase in degradable starch intake (Firkins et al., 2001). This in turn may determine important qualitative changes in digestive processes, particularly in the rumen, which confound the effects of particle size.

Therefore, the objective of the present study was to investigate the effects of varying the dietary particle size of hay on chewing activity, fermentation in the rumen, ruminal mat characteristics, passage, and extent of digestion in dairy cows under a constant intake level (semi ad libitum) at a low and high inclusion of concentrate.

\section{MATERIALS AND METHODS}

\section{Animals, Diets, and Experimental Design}

Four multiparous ruminally cannulated $(\sim 100 \mathrm{~mm}$ in diameter, Bar Diamond, Parma, ID) late-lactating Holstein cows, housed in a tie-stall barn at the experimental unit of the Institute of Animal Nutrition, University of Hohenheim, were included in this research from January to April 2004. Upon commencement of the experiment, cows averaged $195 \pm 36$ DIM (mean \pm SD), produced about $20 \mathrm{~kg} / \mathrm{d}$ of milk, and had an average BW of $665 \pm 49 \mathrm{~kg}$. Cows were bedded with sawdust and milked twice daily in their stalls at 0700 and 1500 $\mathrm{h}$. Cows were weighed at approximately $1000 \mathrm{~h}$ at the beginning and the end of each period, and these weights were used to calculate the mean BW of cows for each period. Animals were cared for in accordance with a protocol approved by the Animal Protection Committee, Federal State of Baden-Württemberg, Germany, and continuous veterinary supervision was provided.

Animals were assigned in a $4 \times 4$ Latin square design with a $2 \times 2$ factorial arrangement of treatments to 4 different diets. The 4 diets $(\mathbf{L F}=$ low concentrate level and fine hay; $\mathbf{L L}=$ low concentrate level and longchopped hay; $\mathbf{H F}=$ high concentrate level and fine hay; HL = high concentrate level and long-chopped hay) were formulated by combining 2 factors, each with 2 levels, namely, 2 different theoretical particle sizes of hay [long $(\mathrm{L}=30 \mathrm{~mm})$ and fine $(\mathrm{F}=6 \mathrm{~mm})$ ] in 2 different concentrate inclusions [DM basis; low (L approximately $20 \%)$ and high ( $\mathrm{H}$ approximately $60 \%)]$. The secondcut, sun-dried hay (56.6\% NDF of DM), mown from the same hayfield, was purchased as big bales $(400 \mathrm{~kg})$ from a private farm in southwestern Germany and was used as the unique forage source in the present study. The long-chopped hay was obtained by chopping the hay with a forage chopper (type 28, Gebrüder Botsch, Bad Rappenau, Germany) set at a $30-\mathrm{mm}$ chop length, whereas the fine hay was obtained by grinding the hay through a 6-mm screen using a Lasco hay mill (Lasco Heu-Technik GmbH, Lochen, Austria). There was no important difference in chemical composition between the fine and long-chopped hay. The low-level concentrate treatments were formulated to have more $\mathrm{CP}$ and vitamin-mineral premix than those of the high-level treatments (Table 1). Wheat and barley grain, as the main components of the concentrate mixture, were ground to pass a 3-mm screen (type DM2-2VD, Skiold, 
Table 1. Information on the chemical composition of feeds ${ }^{1}$ and 4 different treatments tested in the present study

\begin{tabular}{lrrrr}
\hline & \multicolumn{4}{c}{ Treatment $^{2}$} \\
\cline { 2 - 5 } Parameter & LF & LL & HF & HL \\
\hline DM, \% & 88.4 & 88.4 & 88.7 & 88.7 \\
Crude ash, \% of DM & 8.3 & 8.2 & 6.4 & 6.4 \\
CP, \% of DM & 13.0 & 13.1 & 14.5 & 14.6 \\
NDF, \% of DM & 49.0 & 48.4 & 37.6 & 37.3 \\
NDF from hay, \% of DM & 44.9 & 44.0 & 25.3 & 24.9 \\
ADF, \% of DM & 28.5 & 28.0 & 18.7 & 18.4 \\
NFC, \% of DM & 27.9 & 28.4 & 39.5 & 39.7 \\
NE, MJ/kg of DM & 5.84 & 5.88 & 6.99 & 7.01 \\
\hline
\end{tabular}

${ }^{1}$ Chemical composition of the hay, concentrate for the low-level treatment, and concentrate for the high-level treatment (DM basis) were as follows: $8.93,5.69$, and $4.38 \%$ for crude ash; $11.3,19.5$, and $17.1 \%$ for CP; $56.6,19.9$, and $22.1 \%$ for NDF; $21.4,52.6$, and $54.1 \%$ for NFC; $5.25,8.10$, and $8.40 \mathrm{MJ}$ of $\mathrm{NE}_{\mathrm{L}} / \mathrm{kg}$ of $\mathrm{DM}$, respectively. Concentrate of the low-level treatment contained (DM basis) $44 \%$ wheat, $41 \%$ barley, $4 \%$ sugar beet pulp, $6 \%$ soybean meal, $2 \%$ urea, and $3 \%$ vitamin-mineral premix; and concentrate of the high-level treatment contained (DM basis) $44 \%$ wheat, $41 \%$ barley, $7.3 \%$ sugar beet pulp, $5 \%$ soybean meal, $1 \%$ urea, and $1.7 \%$ vitamin-mineral premix. Wheat and barley grain were ground to pass a $3-\mathrm{mm}$ screen.

${ }^{2}$ Treatments: LF = low concentrate level and fine hay; LL = low concentrate level and long hay; $\mathrm{HF}$ = high concentrate level and fine hay; $\mathrm{HL}=$ high concentrate level and long hay.

${ }^{3} \mathrm{NFC}=100-(\% \mathrm{NDF}+\% \mathrm{CP}+\%$ ether extract $+\%$ crude ash $)$.

Sby, Denmark). The diets were formulated to meet the nutrient requirements of a $650-\mathrm{kg}$ cow producing $20 \mathrm{~kg}$ of milk/d with $4 \%$ fat (GfE, 2001).

Experimental periods were $23 \mathrm{~d}$ in duration ( $11 \mathrm{~d}$ of treatment adaptation and $12 \mathrm{~d}$ of data collection). Feed intake was fixed at $17 \mathrm{~kg}$ of DM/d and animals had free access to water. Ingredients (concentrate and hay) of the ration were offered separately to the cows. Dietary hay and low-level concentrate were offered simultaneously to the cows twice daily, at 0800 and $1600 \mathrm{~h}$, whereas concentrate of the high-level treatment was offered in 4 meals a day, at $0800,1200,1600$, and 1900 h. For each cow, the feed trough was divided into 2 adjacent areas, one larger area for hay and another smaller area for concentrate, and the cows could have free access to both areas simultaneously. The eventual orts were collected daily at $0700 \mathrm{~h}$ and subsequently weighed.

\section{Chemical Analyses and Particle Size Distribution of Feeds}

Samples of the feeds and orts were collected on 3 occasions during each data collection period. Dried composite samples were ground to pass a 1-mm screen using a laboratory Retsch mill. The DM content was analyzed by oven-drying at $103^{\circ} \mathrm{C}$ for $4 \mathrm{~h}$. Samples of feeds, orts, and feces were analyzed for ash at $550^{\circ} \mathrm{C}$ overnight and for ether extract and $\mathrm{CP}$ using the $\mathrm{CuSO}_{4} / \mathrm{H}_{2} \mathrm{SO}_{4}$ mixed- catalyst Kjeldahl procedure according to the official analytical methods of the Union of German Agricultural Research Stations (Naumann and Basler, 1997). The methods described by Van Soest et al. (1991) were used in analyses of ADF and NDF, with amylase and sodium sulfite used in the NDF procedure. The particle size distribution of feeds was measured on 3 occasions each period by wet sieving using a vertical oscillating sieve shaker (AS 200 Digit analytical sieve shaker, F. Kurt Retsch GmbH \& Co. KG, Haan, Germany) equipped with a stack of sieves (200 $\mathrm{mm}$ i.d.) arranged in descending pore size. Sieve pore sizes were 6.0, 4.0, 2.0, 1.18, $0.5,0.125$, and $0.063 \mathrm{~mm}$. Particles escaping the $0.063-$ $\mathrm{mm}$ screen were considered the soluble fraction. Duplicate samples of approximately $15 \mathrm{~g}$ of hay or $40 \mathrm{~g}$ of concentrate were soaked in tap water at room temperature for $1 \mathrm{~h}$ before being placed on the top screen, and the stack of sieves was shaken for $12 \mathrm{~min}$, with a water spray of $2.9 \mathrm{~L} / \mathrm{min}$ on the top sieve. The vibration amplitude was held constant ( $2 \mathrm{~mm}$ and an interval pause of $2 \mathrm{~s}$ every $20 \mathrm{~s}$ ). The material retained on the sieves was washed onto preweighed filter paper (No. 5951/2, Schleicher and Schuell, Dassel, Germany), dried at $80^{\circ} \mathrm{C}$ for $24 \mathrm{~h}$, and weighed. The wet-sieving results of hay and concentrate were used to estimate the particle size distribution of the diets based on their real proportions in the diet. The sum of dietary DM remaining on the 6.0-, 4.0-, 2.0-, and 1.18-mm sieves was termed $\mathbf{D M}_{>1.18 \mathrm{~mm}}$. To estimate the mean particle size (MPS) of the diets, particle size data, expressed as cumulative DM percentage oversize, were fitted to the following exponential equation according to Fisher et al. (1988; including the soluble fraction, $0 \mathrm{~mm}=100 \%$ ) using the NLIN procedure (iterative Marquardt method) of SAS (SAS Institute, 2001):

$$
R=100 \mathrm{e}^{-\mathrm{k}(\mathrm{s}-\mathrm{w})}
$$

where $R$ is the percentage of weight greater than any given $\mathrm{s} ; \mathrm{s}$ is the aperture size of sieve-retaining particles; $\mathrm{w}$ is the smallest estimable particle size; and $\mathrm{k}$ is the decay constant of the exponential curve, which indicates the proportion of particles above any given screen size that will pass a sieve 1 unit larger.

The MPS was subsequently calculated as MPS $=1$ / $\mathrm{k}+\mathrm{w}$. The chemical composition of feeds and diets corrected for orts is given in Table 1.

\section{Chewing Activities}

Immediately after an 11-d adaptation period, eating and ruminating activities were recorded over $24 \mathrm{~h}$ for 4 consecutive days in each cow using the technique described by Tafaj et al. (2005a). This is a computer- 
based recording system that allows one to distinguish between eating and ruminating activity based on the regularity of occurrence of the chew patterns in a certain chewing period. Jaw movements, recorded every 6 $\mathrm{s}$, were designated as ruminating chews if, within a 6-s time interval, between 4 and 7 chews were recorded, and when 5 to 12 successive intervals (i.e., the time assumed to be needed for mastication of a bolus) appeared followed by a pause. Within a chewing period, a pause was considered when, within $4 \mathrm{~s}$, no jaw movement occurred (i.e., $4 \mathrm{~s}$ was assumed to be the time needed for swallowing the masticated bolus and regurgitating the next one). The chewing period was then considered as a rumination period when at least 3 consecutive boli occurred separated by pauses. The jaw movements that occurred out of a rumination period were categorized as eating activity. However, fewer than 4 jaw movements within $6 \mathrm{~s}$ was considered to be associated with drinking, licking, or grooming; these were not considered as chewing activity and were therefore deleted. The total time spent chewing was calculated as the total time spent eating and ruminating. To estimate the time spent eating or ruminating per kilogram of DMI or fiber unit, the average intake for those $4 \mathrm{~d}$ was used.

\section{Fractional Rate of Passage of Solids and Fluids, and Digestibility}

Ytterbium-labeled NDF (Yb-NDF) was used as a marker for fractional solid passage rates. A fiber-rich hay ground through a 2-mm screen using a laboratory Retsch mill was used to prepare $\mathrm{Yb}-\mathrm{NDF}$ as described by Mambrini and Peyrand (1997). The fractional passage rate of fluids was measured using LiCo-EDTA as a marker, which was prepared according to the procedure described by Uden et al. (1980). Cows were administered a single dose of $146 \mathrm{~g}$ of $\mathrm{Yb}-\mathrm{NDF}$ and $15 \mathrm{~g}$ of LiCoEDTA via the cannula on $d 12$ of each period at the time of morning feeding. The $\mathrm{Yb}-\mathrm{NDF}$ was placed in the rumen and no attempt was made to manually mix the marker with the ruminal contents, followed by the administration of LiCo-EDTA by means of a flexible plastic tube directly to the ventral rumen. Fecal grab samples were taken at $0,4,8,12,16,20,24,28,32$, $36,40,48,52,56,60,72,80,84,96,104,108,120,128$, 132 , and $144 \mathrm{~h}$ after dosing to determine the fractional passage rates of digesta. Samples were dry-ashed and fecal marker concentrations of $\mathrm{Yb}$ and Co were determined by atomic absorption spectrophotometry (Spectra AA, 220 FS, Varian Australia Pty Ltd., Australia), using a nitrous oxide flame, against a standard with the fecal matrix obtained before dosing (Tafaj et al., 2005a).
Fecal $\mathrm{Yb}$ and Co excretion curves were fitted to the 2-compartment model, both as age-independent (G1G1) and age-dependent (GnG1: $\mathrm{n}=2,3$, and 4) models, as described by Moore et al. (1992). These models estimate fractional passage rates from 2 compartments [fast $\left(\mathrm{k}_{\mathrm{F}}\right)$ and slow $\left(\mathrm{k}_{\mathrm{S}}\right)$, with $\mathrm{k}_{\mathrm{S}}$ representing passage out of the rumen] and include a time delay. Total mean retention time in the digestive tract (TMRT) was calculated as the sum of the mean retention time in the rumen $\left(\mathrm{RMRT}=1 / \mathrm{k}_{\mathrm{S}}\right)$ and in the lower digestive tract $(\mathrm{FMRT}=$ $\mathrm{Gn} / \mathrm{k}_{\mathrm{F}}$ ) plus a time delay. Data were analyzed by the NLIN procedure (iterative Marquardt method) of SAS (SAS Institute, 2001). Criteria for evaluating which model best fit the data were the same as outlined by Moore et al. (1992).

Apparent digestibility of nutrients in the total digestive tract was determined using $\mathrm{TiO}_{2}$ as an external marker (40 g/animal per day was mixed with $1,000 \mathrm{~g}$ of concentrate and fed for $10 \mathrm{~d}$ twice daily, in 2 equal meals, shortly before normal feeding). During the last $7 \mathrm{~d}$, spot-grab fecal samples were collected every $8 \mathrm{~h}$ from the rectum and were pooled and stored at $4^{\circ} \mathrm{C}$. After mixing, subsamples were dried at $65^{\circ} \mathrm{C}$ and ground to pass a 1-mm screen. Procedures for $\mathrm{TiO}_{2}$ analysis and the calculation of apparent nutrient digestibility were described by Tafaj et al. (2005a).

\section{Fermentation in the Rumen}

To measure ruminal fermentation, samples of ruminal fluid $(\sim 250 \mathrm{~mL})$ were collected via rumen cannula (using a vacuum pump) from the ventral rumen at 0100 , $0400,0700,1000,1300,1600,1900$, and $2200 \mathrm{~h}$ on the last $2 \mathrm{~d}$ of chewing activity recording. Ruminal $\mathrm{pH}$ was measured immediately after sampling using a portable pH meter (InLab 412, Mettler-Toledo, Greifensee, Switzerland), which was calibrated before $\mathrm{pH}$ measurements using a pH 4.0 and 7.0 buffer solution. Subsequently, about $100 \mathrm{~mL}$ of ruminal fluid was centrifuged at $2,010 \times g$ for $20 \mathrm{~min}$. Two replicates of supernatant (each of $5 \mathrm{~mL}$ ) were frozen at $-30^{\circ} \mathrm{C}$ for determination of the VFA concentration by GLC, as described by Tafaj et al. (2005b).

In situ disappearance of hay and concentrate DM incubated over $48 \mathrm{~h}$ in the rumen was used as an index of the cellulolytic and amylolytic activity of rumen digesta, respectively. Identical samples of approximately $5 \mathrm{~g}$ of hay or concentrate, dried at $60^{\circ} \mathrm{C}$ for $48 \mathrm{~h}$ and ground to pass through a $2-\mathrm{mm}$ screen, was weighed into Dacron polyester bags $(5 \times 10 \mathrm{~cm})$ with a pore size of $52 \pm 5 \mu \mathrm{m}$ (mean $\pm \mathrm{SD}$ ) and incubated in duplicate in the rumen of 2 cows each period while the cows received the 4 different dietary treatments. Before in- 
sertion into the rumen, bags were soaked in warm water for $10 \mathrm{~min}$ to simulate the addition of saliva.

Bags were placed in large mesh retaining sacs before being incubated ruminally for $0,4,8,12,24,32$, and $48 \mathrm{~h}$. After removal from the rumen, bags were washed under cold, running tap water and then machinewashed according to the procedure described by Cherney et al. (1990). At the 0-h time point, bags were not placed in the rumen but were subjected to the same washing procedure. Bags were dried at $60^{\circ} \mathrm{C}$ for $48 \mathrm{~h}$. The kinetics of DM disappearance in sacco were estimated using the NLIN procedure of SAS (SAS Institute, 2001) by fitting the following model (McDonald, 1981) to the percentage of DM disappearance:

$$
y=a+b \times\left(1-e^{-k_{d}(t-L)}\right) \text { for } t>L,
$$

where $\mathrm{a}$ is the soluble fraction (\%); $\mathrm{b}$ is the insoluble, degradable fraction (\%); $k_{\mathrm{d}}$ is the fractional rate of disappearance $(\% / \mathrm{h})$; L is the lag time $(\mathrm{h})$; and $\mathrm{t}$ is the time of incubation (h). To calculate effective rumen degradability (ERD), the fractional passage rate of $\mathrm{Yb}$ $\operatorname{NDF}\left(k_{\mathrm{s}}\right)$ was included as follows:

$$
\mathrm{ERD}=\mathrm{a}+\mathrm{b} k_{\mathrm{d}} /\left(k_{\mathrm{d}}+k_{\mathrm{s}}\right) .
$$

\section{Digesta Sampling and Determination of Ruminal Digesta Characteristics}

Ruminal digesta characteristics were investigated using, as main indicators, the particle size distribution in the dorsal and ventral rumen sacs, the mat-to-nonmat ratio, and the mat consistency. The differences in digesta particle size from the dorsal to the ventral rumen sac and their dynamics in time were considered as indications of particle breakdown and stratification quality of digesta in the reticulorumen (Sutherland, 1988).

To investigate the particle size distribution in the rumen, particulate digesta samples ( $\sim 300 \mathrm{~g}$ each $)$ were collected at 3 or $23 \mathrm{~h}$ after the morning feeding in the dorsal ( 5 to $10 \mathrm{~cm}$ beneath the top of the particle mat) or ventral (5 to $10 \mathrm{~cm}$ above the rumen floor) rumen sac, according to the technique described by Tafaj et al. (2005b). Immediately after sampling, particle subsamples were used for both DM and NDF determination (Naumann and Basler, 1997) and were stored at $-20^{\circ} \mathrm{C}$ for subsequent analysis of particle size distribution. After thawing, duplicate samples of approximately 40 $\mathrm{g}$ of digesta were soaked in tap water at room temperature for $1 \mathrm{~h}$ before sieving. The sieving procedure and the estimation of MPS of digesta were the same as described above for the analysis of feed particle size distribution.
Consistency of the ruminal mat was measured 4 times, namely, at $0700,1100,1700$, and $2100 \mathrm{~h}$, repeated over 2 consecutive days (on $d 17$ and 18 of each period), using a technique adapted from Welch (1982) with minor modifications regarding the weights used. An 800-g cylindrical $(\sim 40 \mathrm{~mm}$ radius and $100 \mathrm{~mm}$ length), stainless-steel weight was manually placed in the rumen floor via cannula $30 \mathrm{~min}$ prior to measurement (the time needed for reformation of the mat), and the cylinder was attached by the small end. Upon release of an exterior 3,200-g weight (adapted to move freely over a continuously adjustable supporting stand), the ascension time (min) of the 800-g weight from the rumen floor through the ruminal mat to the cannula aperture was recorded. The ascension rate $(\mathrm{cm} / \mathrm{min})$ was calculated by dividing the distance traveled from the rumen floor to the cannula aperture with the ascension time of the weight. The ascension rate was considered to be an indication of ruminal mat consistency: The lower the ascension rate, the thicker the ruminal mat and the greater the mat consistency.

On the last day of each period, the total reticuloruminal contents were manually removed $1 \mathrm{~h}$ prior to the morning feeding. All the ruminal content that could be removed by hand was emptied into a rectangular insulated tub. This material was referred to as the mat. Material not removable by hand was bailed into an insulated plastic barrel. This material was referred to as bailable liquids (Robinson et al., 1987) or nonmat material. Both fractions were weighed, subsampled for subsequent DM and NDF analysis, and then liquids were returned to the rumen, followed by the mat.

\section{Statistical Analysis}

Data were analyzed using the MIXED procedure of SAS (SAS Institute, 2001). The model included cow, period, particle size, concentrate level, and the 2-way interaction between particle size and concentrate level. Chewing activity was analyzed by considering the measurements on $4 \mathrm{~d}$ as longitudinal repeated measures with a first-order autoregressive covariance structure, which showed the best fit according to the Akaike information criterion (AIC, "smaller is better").

For the analysis of ruminal mat consistency and ruminal fermentation parameters, the effect of measuring time was also included in the model by considering the measurements as longitudinal repeated measures with a spatial power covariance structure [sp(pow) (time)] according to the AIC. For particle size distribution data, the model included the effects of sampling site (dorsal vs. ventral, S) and sampling time (3 vs. $23 \mathrm{~h}, \mathrm{~T}$ ), considering the measurements in the same animal at different $\mathrm{S}$ and $\mathrm{T}$ as duplicate repeated measures (spatial and 
Table 2. Effects of dietary hay particle size and concentrate level on BW, feed intake, and particle size distribution of 4 experimental diets tested in the present study

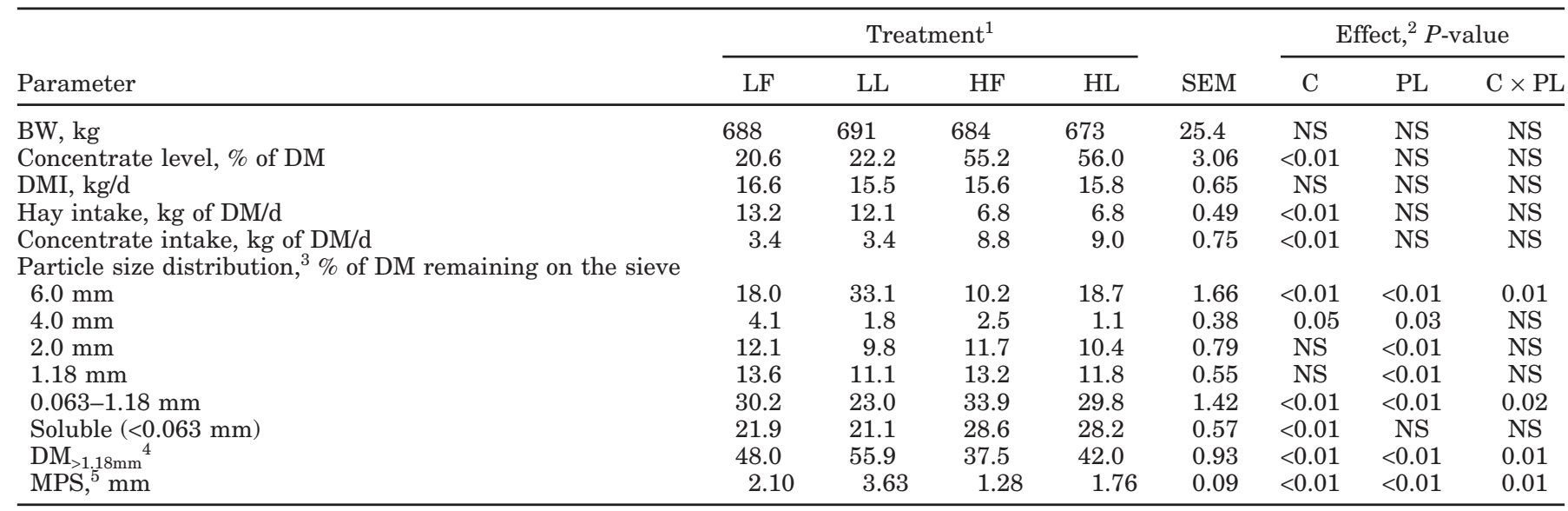

${ }^{1}$ Treatments: LF = low concentrate level and fine hay; LL = low concentrate level and long hay; HF = high concentrate level and fine hay; $\mathrm{HL}=$ high concentrate level and long hay.

${ }^{2}$ Effect of concentrate level (C) and hay particle size (PL) and their 2-way interaction $(\mathrm{C} \times \mathrm{PL})$; NS $=P>0.15$.

${ }^{3}$ Estimated based on wet-sieving particle distribution of hay and concentrate using a vertical oscillating sieve shaker. Particles retained on sieves $6.0,4.0,2.0,1.18,0.063-1.18$, and $<0.063 \mathrm{~mm}$ (\% of DM) were, respectively, 22.7, 5.2, 12.4, 13.9, 27.9, and $17.9 \%$ for fine hay; 42.6 , $2.3,9.5,10.7,18.5$, and $16.5 \%$ for long hay; $0,0.3,11.0,12.6,38.8$, and $37.4 \%$ for concentrates.

${ }^{4} \mathrm{DM}_{>1.18 \mathrm{~mm}}=\mathrm{DM}$ of diet retained on sieves $6.0,4.0,2.0$, and $1.18 \mathrm{~mm}$ (determined by the wet-sieving procedure).

${ }^{5}$ Mean particle size of diets estimated by wet-sieving data according to Fisher et al. (1988, including the soluble fraction); $100 \mathrm{e}^{-\mathrm{k}(\mathrm{s}-\mathrm{w})}$, where $\mathrm{s}$ is the screen size, and $\mathrm{k}$ and $\mathrm{w}$ are the fitted parameters.

time repeated measures). The model with the best fit according to the AIC was a model using an unstructured covariance structure for $\mathrm{S}$ and first-order autoregressive covariance structure for T [UN@AR (1)]. Data on the particle size distribution of the diets were averaged per period and analyzed by considering the fixed effects of particle size and concentrate level, the 2 -way interaction between particle size and concentrate level, and the random effect of replications within treatment. The degrees of freedom were adjusted with the KenwardRoger method. Least squares means were computed and multiple differences were tested using the PDiff option of SAS. Significance was declared at $P<0.05$ and a tendency was considered up to $P<0.15$.

\section{RESULTS}

\section{Intake and Particle Size Distribution of Diets}

Data on the intake of dietary ingredients and total DMI are shown in Table 2. Dry matter intake was held constant in this study ( $120 \mathrm{~g} / \mathrm{kg}$ of metabolic weight). Cows fed a low-concentrate diet consumed all the concentrate amount offered ( $3.4 \mathrm{~kg}$ of DM), but refused 0.4 and $1.5 \mathrm{~kg}$ of DM hay when finely and coarsely chopped hay was fed, respectively. On the other hand, cows fed high-concentrate diets consumed all the hay offered (6.8 $\mathrm{kg}$ of DM), but refused 1.4 and $1.2 \mathrm{~kg}$ of DM concentrate when a finely and coarsely chopped hay was fed, respectively.
Data on the particle size distribution of feeds, determined by wet-sieving, and diets calculated according to the proportion of feeds in the ration, are shown in Table 2. The long-chopped hay had significantly more large particles (i.e., particles retained on the $6-\mathrm{mm}$ sieve) than fine hay, and this was reflected in an increased portion of large particles and MPS for diets composed of long hay within the concentrate level treatment. On the other hand, increasing the dietary concentrate level decreased the proportion of large particles and MPS of the diets $(P<0.01)$. Altering the hay particle size from 6 to $30 \mathrm{~mm}$ in the high-concentrate diets increased the proportion of large particles by about $8 \%$ and $\mathrm{DM}_{>1.18 \mathrm{~mm}}$ by about $4.5 \%$, whereas in the low-concentrate diets these fractions were increased by about 15 and 8\%, respectively. Although the LF and HL diets had apparently similar amounts of large particles, the $\mathrm{LF}$ diet had a higher proportion of $\mathrm{DM}_{>1.18 \mathrm{~mm}}$ and a longer MPS (Table 2).

\section{Chewing Activities and Fermentation in the Rumen}

Animal responses to dietary treatments concerning chewing activities are shown in Table 3 . Increasing the dietary concentrate level reduced the eating activity $(P$ $<0.05$ ), either as the number of eating chews per DM unit ingested or as the eating time. In contrast, forage particle size, as offered in this study, did not affect the eating activity $(P>0.15)$. The response of eating activity 
Table 3. Effects of dietary hay particle size and concentrate level on chewing activity in dairy cows

\begin{tabular}{|c|c|c|c|c|c|c|c|c|}
\hline \multirow[b]{2}{*}{ Parameter } & \multicolumn{4}{|c|}{ Treatment $^{1}$} & \multirow[b]{2}{*}{ SEM } & \multicolumn{3}{|c|}{ Effect, ${ }^{2} P$-value } \\
\hline & $\mathrm{LF}$ & LL & $\mathrm{HF}$ & HL & & $\mathrm{C}$ & PL & $\mathrm{C} \times \mathrm{PL}$ \\
\hline \multicolumn{9}{|l|}{ Eating activity } \\
\hline Chews/g of DM & 1.59 & 1.66 & 0.99 & 0.94 & 0.07 & $<0.01$ & NS & NS \\
\hline Min/d & 367 & 412 & 283 & 270 & 37.9 & 0.03 & NS & NS \\
\hline $\mathrm{Min} / \mathrm{kg}$ of $\mathrm{DM}$ & 22.2 & 25.8 & 16.9 & 15.8 & 2.43 & 0.03 & NS & NS \\
\hline $\mathrm{Min} / \mathrm{kg}$ of $\mathrm{DM}_{>1.18 \mathrm{~mm}^{3}}$ & 48.6 & 45.5 & 43.9 & 37.8 & 3.07 & 0.04 & 0.13 & NS \\
\hline $\mathrm{Min} / \mathrm{kg}$ of NDF & 54.7 & 52.2 & 46.6 & 42.3 & 3.86 & 0.07 & NS & NS \\
\hline \multicolumn{9}{|l|}{ Ruminating activity } \\
\hline Chews/g of DM & 1.42 & 1.69 & 0.83 & 1.26 & 0.11 & $<0.01$ & 0.01 & NS \\
\hline $\mathrm{Min} / \mathrm{d}$ & 351 & 405 & 242 & 341 & 25.1 & 0.02 & 0.04 & NS \\
\hline $\mathrm{Min} / \mathrm{kg}$ of $\mathrm{DM}$ & 21.1 & 25.1 & 14.5 & 20.0 & 1.34 & 0.01 & 0.03 & NS \\
\hline $\mathrm{Min} / \mathrm{kg}$ of $\mathrm{DM}_{>1.18 \mathrm{~mm}}$ & 48.4 & 43.7 & 35.4 & 48.2 & 3.68 & NS & NS & 0.02 \\
\hline $\mathrm{Min} / \mathrm{kg}$ of NDF & 57.6 & 51.4 & 40.0 & 53.4 & 6.71 & NS & NS & NS \\
\hline \multicolumn{9}{|l|}{ Total chewing activity } \\
\hline Chews/g of DM & 3.00 & 3.36 & 1.83 & 2.19 & 0.15 & $<0.01$ & 0.03 & NS \\
\hline $\mathrm{Min} / \mathrm{d}$ & 719 & 816 & 524 & 610 & 37.6 & 0.03 & 0.06 & NS \\
\hline $\mathrm{Min} / \mathrm{kg}$ of $\mathrm{DM}$ & 43.3 & 50.9 & 31.3 & 35.7 & 2.40 & 0.03 & 0.05 & NS \\
\hline $\mathrm{Min} / \mathrm{kg}$ of $\mathrm{DM}_{>118 \mathrm{~mm}}$ & 97.0 & 89.2 & 79.3 & 85.9 & 4.96 & 0.03 & NS & 0.14 \\
\hline $\mathrm{Min} / \mathrm{kg}$ of NDF & 112.4 & 103.6 & 86.7 & 95.7 & 6.70 & 0.06 & NS & NS \\
\hline
\end{tabular}

${ }^{1}$ Treatments: $\mathrm{LF}=$ low concentrate level and fine hay; LL = low concentrate level and long hay; $\mathrm{HF}=$ high concentrate level and fine hay; HL = high concentrate level and long hay.

${ }^{2}$ Effect of concentrate level (C) and hay particle size (PL) and their 2-way interaction $(\mathrm{C} \times \mathrm{PL})$; NS $=P$ $>0.15$.

${ }^{3} \mathrm{DM}_{>1.18 \mathrm{~mm}}=\mathrm{DM}$ of diet retained on sieves $6.0,4.0,2.0$, and $1.18 \mathrm{~mm}$ (determined by the wet-sieving procedure).

to dietary particle size and concentrate level was also reflected by the total chewing activity of the cows. Thus, cows chewed between 31.3 and 35.7 in total, and between 43.3 and $50.9 \mathrm{~min} / \mathrm{kg}$ of DM ingested, when a high and a low level of concentrate was offered, respectively. On the other hand, rumination intensity (ruminating chews per kilogram of DM ingested) and daily time spent ruminating were significantly reduced with decreasing hay particle size $(P=0.04)$ and increasing concentrate level $(P=0.02)$ in the diet. However, as shown in Table 3, cows spent a significantly longer time ruminating per kilogram of $\mathrm{DM}_{>1.18 \mathrm{~mm}}$ when the fine hay was fed in a low-concentrate diet (LF diet) or, in particular, when a high level of concentrate was offered together with long hay (HL diet). In other words, rumination time was increased by about 5 and $13 \mathrm{~min} / \mathrm{kg}$ of $\mathrm{DM}_{>1.18 \mathrm{~mm}}$ for the LF and HL diets, compared with the LL and HF diets, respectively.

The daily variation in ruminating activity is shown in Figure 1A. In general, cows increased their ruminating activity during the night and tended to reduce it prior to the morning feeding. Ruminating time was lowest around 0800 and $1600 \mathrm{~h}$, which corresponds to the time when hay and concentrate were offered. Diurnal variation of the ruminal VFA concentration and $\mathrm{pH}$ is shown in Figure $1 \mathrm{~B}$ and $1 \mathrm{C}$.

Results showing the effects of dietary treatments on the disappearance of hay and concentrate DM samples incubated over $48 \mathrm{~h}$ in the rumen using nylon bags are listed in Table 4. Cows fed long hay tended to increase the proportion of in situ potentially degradable hay DM only on the low-concentrate diet, whereas on the high-concentrate diet, the opposite effect was observed, demonstrating an interaction between the 2 dietary factors $(P=0.08)$. This was also reflected in a significant improvement in ERD for the LL diet and a reduction in ERD for the HL diet $(P=0.04)$. In general, the dietary concentrate level tended to negatively affect the in situ ERD percentage of hay DM $(P=$ 0.07), whereas the in situ disappearance of concentrate DM was unaffected by dietary treatments in the present study.

\section{Particle Size Distribution and Ruminal Mat Characteristics}

Data on particle size distribution of the rumen digesta are shown in Table 5. As the particle size of dietary hay increased, the fraction of large particles $(>6 \mathrm{~mm})$ also increased $(P<0.01)$, which was reflected by a longer MPS, at both $3(P=0.04)$ and $23 \mathrm{~h}$ after the morning feeding $(P=0.07)$. Conversely, in either measurement time, the proportion of small particles (0.063 to $1.18 \mathrm{~mm})$ significantly decreased with increasing dietary particle size in both the dorsal and ventral rumen sac. On the other hand, the proportion of small particles decreased from 47.2 to $42.3 \%$ by 

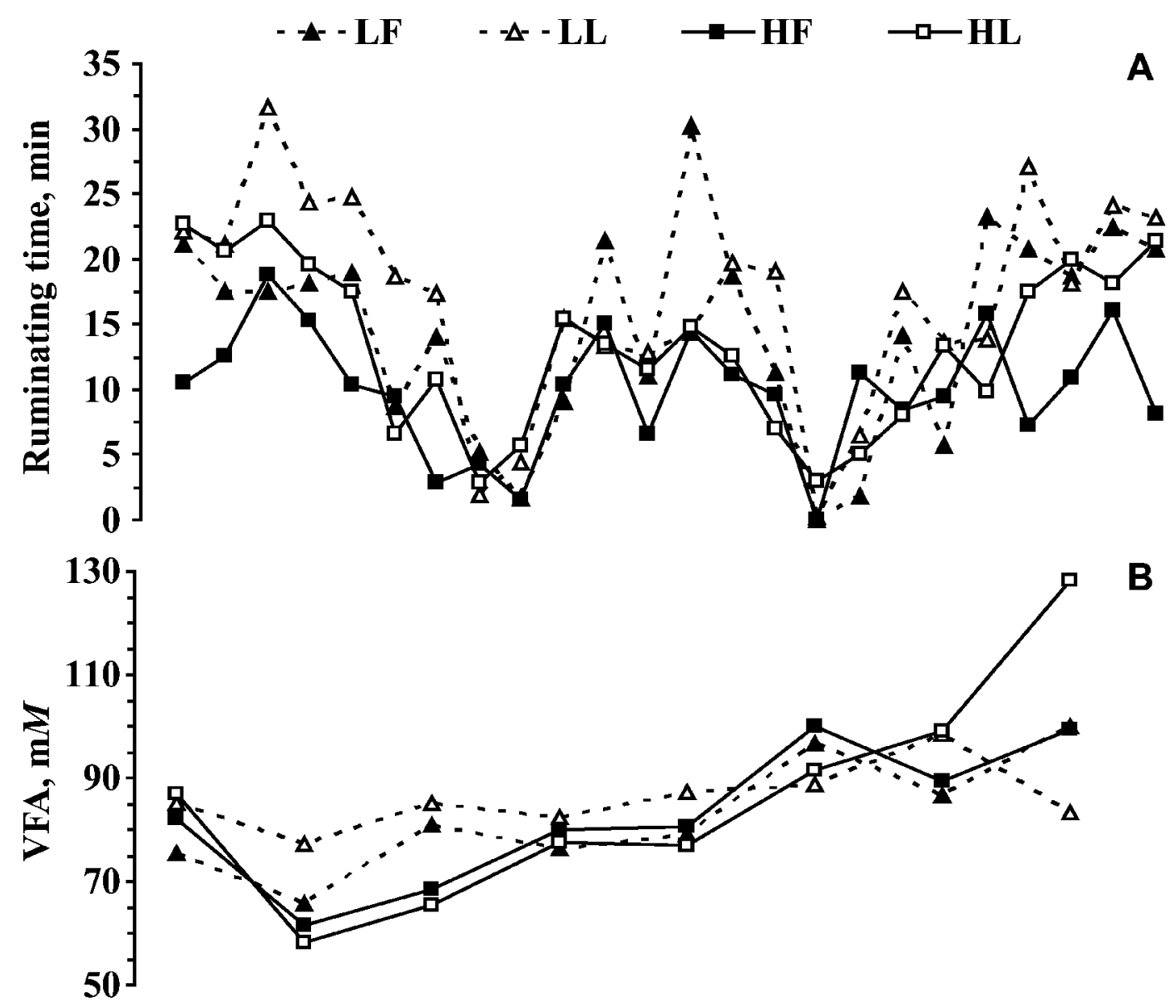

B

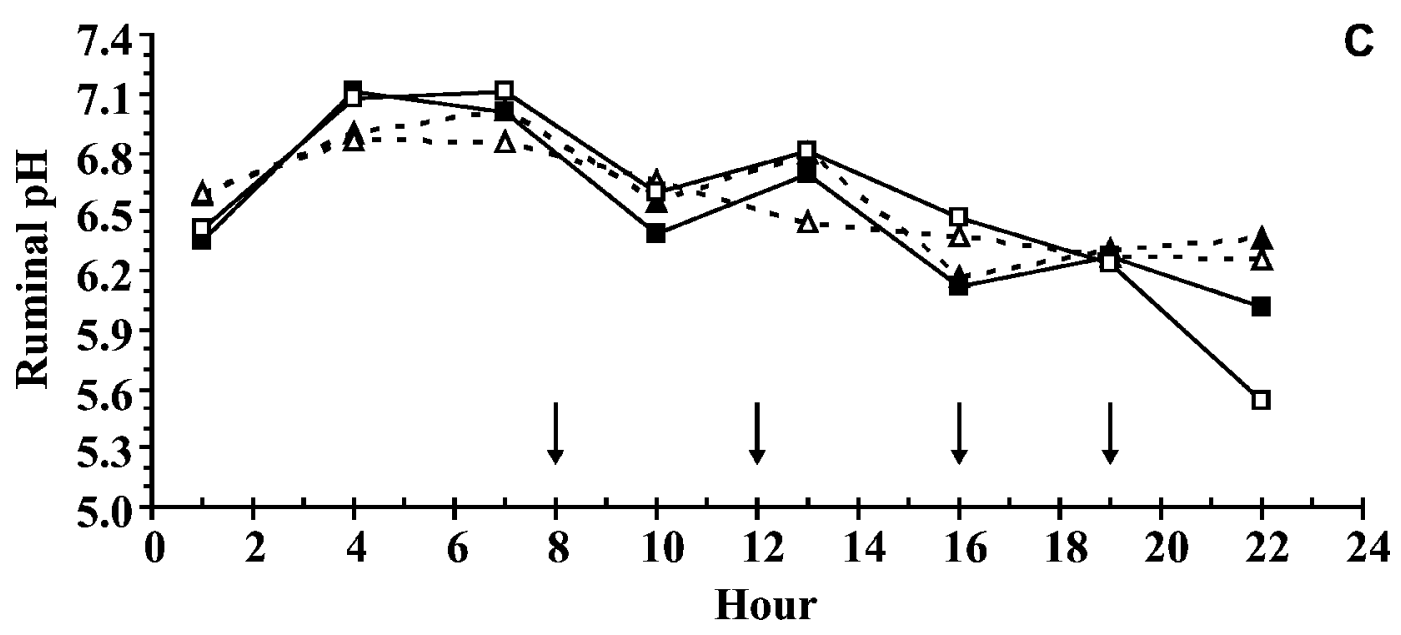

Figure 1. Daily variation of rumination activity (A), ruminal VFA concentration (B), and pH (C) for 4 treatments: LF = low concentrate level and fine hay; LL = low concentrate level and long hay; HF = high concentrate level and fine hay; HL = high concentrate level and long hay. Feeding times $(\downarrow)$ : dietary hay and low-level concentrate were offered twice daily at 0800 and $1600 \mathrm{~h}$, whereas concentrate of the high-level treatment was offered in 4 meals a day at 0800, 1200, 1600, and $1900 \mathrm{~h}$.

elevating the dietary concentrate level when measured $3 \mathrm{~h}$ after the morning feeding $(P=0.12)$.

There was a higher DM content in the dorsal rumen sac than in the ventral rumen sac, and this was higher
$3 \mathrm{~h}$ after the morning feeding (results not shown). In addition, as shown in Table 5, the proportion of small particles was significantly higher in the ventral rumen sac measured $3 \mathrm{~h}$ after the morning feeding $(P=0.03)$, 
Table 4. The disappearance of DM for hay and concentrate incubated in situ as diets with 2 different hay particle size and concentrate levels were fed to dairy cows

\begin{tabular}{|c|c|c|c|c|c|c|c|c|}
\hline \multirow[b]{2}{*}{ Parameter } & \multicolumn{4}{|c|}{ Treatment $^{1}$} & \multirow[b]{2}{*}{ SEM } & \multicolumn{3}{|c|}{ Effect, ${ }^{2} P$-value } \\
\hline & $\mathrm{LF}$ & LL & $\mathrm{HF}$ & HL & & $\mathrm{C}$ & PL & $\mathrm{C} \times \mathrm{PL}$ \\
\hline \multicolumn{9}{|c|}{ Hay DM } \\
\hline \multicolumn{9}{|c|}{ Fraction, ${ }^{3} \%$ of DM } \\
\hline $\mathrm{b}$ & 57.1 & 68.9 & 62.3 & 52.4 & 3.43 & NS & NS & 0.08 \\
\hline $\mathrm{k}_{\mathrm{d}}, \% / \mathrm{h}$ & 5.35 & 6.13 & 5.03 & 4.33 & 0.44 & 0.10 & NS & NS \\
\hline $\mathrm{ERD},{ }^{4} \%$ & 57.6 & 71.3 & 57.3 & 49.2 & 2.39 & 0.07 & NS & 0.04 \\
\hline \multicolumn{9}{|c|}{ Concentrate DM } \\
\hline \multicolumn{9}{|c|}{ Fraction, \% of DM } \\
\hline $\mathrm{a}$ & 52.1 & 54.0 & 51.7 & 52.2 & 1.96 & NS & NS & NS \\
\hline $\mathrm{b}$ & 40.8 & 38.6 & 41.7 & 40.3 & 2.65 & NS & NS & NS \\
\hline $\mathrm{k}_{\mathrm{d}}, \% / \mathrm{h}$ & 26.7 & 23.5 & 20.8 & 25.2 & 4.14 & NS & NS & NS \\
\hline ERD, \% & 88.5 & 88.0 & 87.8 & 88.0 & 1.75 & NS & NS & NS \\
\hline
\end{tabular}

${ }^{1}$ Treatments: $\mathrm{LF}=$ low concentrate level and fine hay; $\mathrm{LL}=$ low concentrate level and long hay; $\mathrm{HF}=$ high concentrate level and fine hay; $\mathrm{HL}=$ high concentrate level and long hay.

${ }^{2}$ Effect of dietary concentrate level $(\mathrm{C})$, hay particle size $(\mathrm{PL})$, and their 2 -way interaction $(\mathrm{C} \times \mathrm{PL})$; $\mathrm{NS}=$ $P>0.15$.

${ }^{3}$ Fractions: $a=$ soluble fraction; $\mathrm{b}=$ insoluble, degradable fraction; $\mathrm{k}_{\mathrm{d}}=$ fractional rate of disappearance.

${ }^{4}$ Effective rumen degradability calculated using ruminal fractional rate of passage $\left(\mathrm{k}_{\mathrm{s}}\right)$ of ytterbiumlabeled NDF $\left[\mathrm{ERD}=\mathrm{a}+\mathrm{b} \mathrm{k}_{\mathrm{d}} /\left(\mathrm{k}_{\mathrm{d}}+\mathrm{k}_{\mathrm{s}}\right)\right]$.

whereas at $23 \mathrm{~h}$ after the morning feeding, this difference was minimized $(P=0.10)$.

The dynamic changes in particle size from the diets (shown in Table 2) to ruminal digesta were more evident for treatments with a low level of concentrate. Yet the most important reduction of large particles $(>6.0 \mathrm{~mm})$ was observed at an early (3-h) measurement time, whereas at the later measurement time $(23 \mathrm{~h})$ no fur-

Table 5. Effect of treatments ${ }^{1}$ on particle size distribution ${ }^{2}$ (DM retained on the sieve, $\%$ of total), mean particle size, and NDF content of ruminal digesta measured at 2 sampling sites ${ }^{3}$ and times

\begin{tabular}{|c|c|c|c|c|c|c|c|c|c|c|c|c|c|c|}
\hline Time $^{4}$ & Item & \multicolumn{4}{|c|}{ Dorsal sac } & \multicolumn{4}{|c|}{ Ventral sac } & SEM & \multicolumn{4}{|c|}{ Effects ${ }^{5} P$-value } \\
\hline \multirow[t]{6}{*}{$3 \mathrm{~h}$} & Screen size, mm & & & & & & & & & & & & & \\
\hline & 4.0 & $\begin{array}{l}0.51 \\
02\end{array}$ & 0.85 & 0.67 & $\begin{array}{l}0.73 \\
268\end{array}$ & $\begin{array}{l}0.67 \\
5\end{array}$ & $\begin{array}{l}0.69 \\
1.90\end{array}$ & $\begin{array}{l}0.98 \\
2.93\end{array}$ & $\begin{array}{l}1.22 \\
3.15\end{array}$ & $\begin{array}{l}0.31 \\
159\end{array}$ & NS & NS & $\begin{array}{l}\mathrm{NS} \\
\mathrm{NS}\end{array}$ & $\begin{array}{l}0.06 \\
N S\end{array}$ \\
\hline & 2.0 & 2.23 & 2.66 & 2.96 & $\begin{array}{l}2.68 \\
572\end{array}$ & $\begin{array}{l}5.21 \\
8.85\end{array}$ & 1.90 & 2.93 & 3.15 & 1.52 & NS & NS & NS & NS \\
\hline & 1.18 & 7.65 & 7.43 & 8.66 & 5.72 & 8.85 & 6.41 & 9.43 & 6.22 & 1.24 & NS & 0.06 & NS & NS \\
\hline & $\mathrm{MPS},{ }^{6} \mathrm{~mm}$ & 0.64 & 1.55 & 0.62 & 1.69 & 0.83 & 1.32 & 0.56 & 1.06 & 0.24 & NS & 0.04 & NS & NS \\
\hline & $\mathrm{NDF}, \%$ of DM & 69.2 & 72.2 & 68.7 & 70.3 & 70.5 & 68.0 & 69.3 & 68.3 & 1.54 & NS & NS & NS & NS \\
\hline \multirow[t]{5}{*}{$23 \mathrm{~h}$} & Screen size, mm & & & & & & & & & & & & & \\
\hline & 6.0 & 13.3 & 22.8 & 11.3 & 22.7 & 10.8 & 18.4 & 11.1 & 24.7 & 3.24 & NS & $<0.01$ & NS & 0.11 \\
\hline & 4.0 & 0.32 & 0.30 & 0.57 & 0.40 & 0.32 & 0.28 & 0.44 & 0.45 & 0.16 & NS & NS & NS & NS \\
\hline & 2.0 & 1.43 & 1.90 & 2.43 & 1.72 & 1.31 & 0.92 & 2.23 & 1.91 & 0.61 & NS & NS & NS & 0.15 \\
\hline & 1.18 & 6.22 & 5.29 & 7.13 & 4.57 & 6.17 & 4.47 & 7.47 & 5.13 & 0.99 & NS & 0.05 & NS & NS \\
\hline
\end{tabular}

${ }^{1}$ Treatments: $\mathrm{LF}$ = low concentrate level and fine hay; LL = low concentrate level and long hay; HF = high concentrate level and fine hay; $\mathrm{HL}=$ high concentrate level and long hay.

${ }^{2}$ Measured by wet-sieving using a vertical oscillating sieve shaker.

${ }^{3}$ Samples collected from dorsal and ventral rumen sac.

${ }^{4}$ Samples collected at $3(1100 \mathrm{~h})$ or $23 \mathrm{~h}(0700 \mathrm{~h})$ after (or $1 \mathrm{~h}$ prior to) the morning feeding.

${ }^{5}$ Effect of concentrate level (C), hay particle size (PL), their 2-way interaction (C $\times$ PL), and sampling site $(\mathrm{S}) ; \mathrm{NS}=P>0.15$.

${ }^{6}$ Mean particle size estimated according to Fisher et al. (1988, including the soluble fraction); $100 \mathrm{e}^{-\mathrm{k}(\mathrm{s}-\mathrm{w})}$, where $\mathrm{s}$ is the screen size, and $\mathrm{k}$ and $\mathrm{w}$ are fitted parameters. 
Table 6. Effects of dietary particle size and concentrate level on ruminal mat consistency ${ }^{1}$ in dairy cows

\begin{tabular}{|c|c|c|c|c|c|c|c|c|}
\hline \multirow{2}{*}{$\begin{array}{l}\text { Measuring } \\
\text { time, h }\end{array}$} & \multicolumn{4}{|c|}{ Treatment $^{2}$} & \multirow[b]{2}{*}{ SEM } & \multicolumn{3}{|c|}{ Effect, ${ }^{3} P$-value } \\
\hline & $\mathrm{LF}$ & LL & $\mathrm{HF}$ & HL & & $\mathrm{C}$ & PL & $\mathrm{C} \times \mathrm{PL}$ \\
\hline 0700 & 30.8 & 19.9 & 92.9 & 34.9 & 10.7 & $<0.01$ & 0.02 & 0.07 \\
\hline 1100 & 11.5 & 5.2 & 62.9 & 12.7 & 10.2 & 0.03 & 0.03 & 0.07 \\
\hline 1700 & 5.3 & 3.6 & 17.5 & 5.2 & 2.30 & 0.02 & 0.02 & 0.06 \\
\hline 2100 & 8.7 & 3.7 & 53.3 & 10.6 & 13.4 & 0.10 & 0.13 & NS \\
\hline
\end{tabular}

\footnotetext{
${ }^{1}$ Measured as ascension rate $(\mathrm{cm} / \mathrm{min})$; a lower number indicates a thicker ruminal digesta mat.

${ }^{2}$ Treatments: $\mathrm{LF}=$ low concentrate level and fine hay; $\mathrm{LL}=$ low concentrate level and long hay; $\mathrm{HF}=$ high concentrate level and fine hay; HL = high concentrate level and long hay.

${ }^{3}$ Effect of concentrate level (C), particle size (PL), and their 2-way interaction $(\mathrm{C} \times \mathrm{PL}) ; \mathrm{NS}=P>0.15$.
}

ther reduction was noticed (Table 5). However, the proportion of particles retained on the 4.0-, 2.0-, and 1.18$\mathrm{mm}$ sieves significantly reduced from the 3 -h to the 23 h measurement $(P<0.05$, results not shown).

As shown in Table 6, both particle size and concentrate level affected the ruminal mat consistency, especially up to $1700 \mathrm{~h}(P<0.05)$, which corresponds to the time when the second portion of hay and concentrate (third portion of concentrate for the high-level concentrate treatment) was already offered. The ascension rate was significantly lower when a low level of concentrate and coarsely chopped hay were fed, reflecting a more consistent, hard-packed ruminal mat. Conversely, the consistency of ruminal digesta was typically lower in cows consuming the HF diet, especially prior to the morning feeding. After the morning feeding, the ascension rate decreased linearly even for diets having a high concentrate level $(P<0.05)$ up to the measurement at $1700 \mathrm{~h}$, after which the ascension rate increased again.

\section{Rumen Fill, Passage, and Total Tract Digestibility}

As shown in Table 7, increasing the concentrate level and reducing the hay particle size decreased the total ruminal contents per kilogram of BW $(P<0.05)$. The mat, as a percentage of total fresh digesta in the reticulorumen, was higher on diets with a low concentrate level $(P=0.03)$. In addition, as the concentrate level in the ration increased, even though coarsely chopped hay was offered (HL diet), the mat proportion decreased $(P=0.09)$ and the bailable liquids increased $(P=0.06)$. This treatment also had the highest fractional passage rate of solids and the highest retention time distally to the reticulorumen $(P<0.10)$, so that the total mean retention time was in between that of the other treatments (Table 7). No differences in total tract fiber digestibility were observed among treatments $(P>0.15)$, even though the DM digestibility was higher when a high concentrate level was fed $(P<0.05)$.

\section{DISCUSSION}

\section{Particle Size Distribution of Diets, Chewing Activities, and Fermentation in the Rumen}

The differences in particle size fractions of the diets, and particularly differences in $\mathrm{DM}_{>1.18 \mathrm{~mm}}$, were reflected in the chewing or rumination activity results in this study. Mertens (1997) postulated that particles $>1.18 \mathrm{~mm}$ would more effectively stimulate chewing than particles below that size, because the latter readily pass out of the rumen and provide fewer stimuli for chewing.

However, in the present study cows spent, in total, more than $31 \mathrm{~min}$ chewing/kg of DM ingested, even when fine hay and a high concentrate level were fed. This value is higher than that proposed by Sudweeks et al. (1981), who quoted values equal to or greater than $30 \mathrm{~min} / \mathrm{kg}$ of $\mathrm{DM}$ as suitable for limiting the risk of digestive disorders. This is presumably due to the relatively high fiber content of the diets ( $>37 \%$ dietary $\mathrm{NDF}$ ), distribution of concentrates over several meals daily (less than $2.8 \mathrm{~kg} / \mathrm{meal}$ ), and controlled low intake in the present study.

The lack of an effect of particle size on eating activity and a positive effect on rumination time agrees with results previously reported in other studies. Thus, Kononoff and Heinrichs (2003) and Yang and Beauchemin (2006) reported that the particle size of alfalfa haylage or barley silage did not affect the eating time but reduced the ruminating time in dairy cows. In the present study, cows spent more time ruminating per unit of $\mathrm{DM}_{>1.18 \mathrm{~mm}}$ when the concentrate level in the ration increased, especially in combination with coarsely chopped hay, which indicates a higher ruminating efficiency for each long-fiber unit ingested. This finding indicates that forage particle size can affect ruminating activity, either by increasing the marginal ruminating time (LL diet) or by extending the ruminating rate per unit of physical fiber ingested (i.e., ruminating chews/ minute per unit of long fiber ingested, in the HL diet). 
Table 7. Effects of dietary hay particle size and concentrate level on rumen fill, fractional passage rate of digesta, and total tract digestibility in dairy cows

\begin{tabular}{|c|c|c|c|c|c|c|c|c|}
\hline \multirow[b]{2}{*}{ Parameter } & \multicolumn{4}{|c|}{ Treatment $^{1}$} & \multirow[b]{2}{*}{ SEM } & \multicolumn{3}{|c|}{ Effect, ${ }^{2} P$-value } \\
\hline & $\mathrm{LF}$ & LL & $\mathrm{HF}$ & HL & & $\mathrm{C}$ & PL & $\mathrm{C} \times \mathrm{PL}$ \\
\hline \multicolumn{9}{|l|}{ Rumen fill ${ }^{3}$} \\
\hline Rumen content, ${ }^{4} \mathrm{~kg} / 100 \mathrm{~kg}$ of $\mathrm{BW}$ & 10.7 & 11.3 & 8.2 & 9.4 & 0.28 & $<0.01$ & 0.02 & NS \\
\hline Mat, \% of total fresh digesta & 83.2 & 91.6 & 81.2 & 78.7 & 2.63 & 0.03 & NS & 0.09 \\
\hline Bailable liquids ${ }^{5} \mathrm{~kg}$ & 12.5 & 6.5 & 10.1 & 13.1 & 1.91 & NS & NS & 0.06 \\
\hline \multicolumn{9}{|l|}{ Fractional passage rate of digesta ${ }^{6}$} \\
\hline $\mathrm{k}_{\mathrm{s}}, \% / \mathrm{h}$ & 3.2 & 2.7 & 3.4 & 4.0 & 0.37 & NS & NS & 0.08 \\
\hline FMRT, h & 14.7 & 12.4 & 13.0 & 20.9 & 2.52 & 0.08 & NS & NS \\
\hline TMRT, h & 56.9 & 56.5 & 51.8 & 54.1 & 2.21 & NS & NS & 0.06 \\
\hline $\mathrm{k}_{\mathrm{l}}, \% / \mathrm{h}$ & 14.3 & 11.7 & 10.9 & 11.3 & 1.06 & 0.05 & 0.12 & 0.02 \\
\hline \multicolumn{9}{|l|}{ Total tract digestibility, $\%$} \\
\hline $\mathrm{DM}$ & 59.2 & 62.1 & 72.0 & 69.8 & 2.67 & 0.04 & NS & 0.08 \\
\hline NDF & 48.8 & 54.9 & 53.7 & 49.8 & 4.68 & NS & NS & NS \\
\hline $\mathrm{ADF}$ & 38.6 & 37.5 & 39.6 & 34.1 & 5.51 & NS & NS & NS \\
\hline
\end{tabular}

${ }^{1}$ Treatments: LF = low concentrate level and fine hay; LL = low concentrate level and long hay; $\mathrm{HF}=$ high concentrate level and fine hay; $\mathrm{HL}=$ high concentrate level and long hay.

${ }^{2}$ Effect of concentrate level (C), hay particle size (PL), and their 2-way interaction $(\mathrm{C} \times \mathrm{PL})$; NS $=P>$ 0.15 .

${ }^{3}$ Rumen fill data were collected after manually emptying the reticulorumen $1 \mathrm{~h}$ prior to the morning feeding.

${ }^{4}$ Total fresh digesta in the reticulorumen.

${ }^{5}$ Rumen material not removable by hand during the evacuation (according to Robinson et al., 1987).

${ }^{6} \mathrm{k}_{\mathrm{s}}=$ fractional passage rate of ytterbium-labeled NDF (solid digesta) from the reticulorumen; FMRT = postruminal mean retention time; TMRT $=$ total mean retention time; $\mathrm{k}_{\mathrm{l}}=$ fractional passage rate of CoEDTA (fluid digesta) from the reticulorumen.

However, results from recent studies (Kononoff and Heinrichs, 2003; Yang and Beauchemin, 2006) in highyielding dairy cows fed a TMR ad libitum have highlighted that increasing rumination or chewing time does not necessarily lead to improved rumen conditions. In agreement with these reports, this study demonstrated that a longer time spent ruminating or chewing caused by increasing the particle size of hay in the ration containing a high level of concentrate was reflected neither in increased ruminal $\mathrm{pH}$ nor in improved in situ fiber degradation and particle breakdown in the rumen. This result suggests that measuring chewing or rumination activity alone cannot be sufficient to estimate the physical effectiveness or fiber adequacy in dairy cows, particularly when high-concentrate diets are fed separately. The reason for this could presumably be the incapacity of saliva flow alone to neutralize the increasing quantities of fermentation acids produced after ingesting high amounts of ruminally degradable OM. In this context, Allen (1997) stated that neutralization by salivary buffers is important in maintaining ruminal $\mathrm{pH}$, but the relative importance of neutralization in hydrogen ion removal from the rumen changes with the amount of VFA produced. However, it should be noted that results of the present study are relevant for cows fed dietary ingredients separately. Therefore, these results may not necessarily represent the response under conditions of TMR feeding, in which a better mixing of dietary ingredients may have diverse effects on intake patterns, chewing activity, passage rate, and hence presumably contribute to leveling the peak of acid production in the rumen.

In the present study, cows fed low-concentrate diets, even with ground hay, showed a higher ruminal $\mathrm{pH}$ and higher in situ hay DM degradability, which indicates a higher capacity of ruminal digesta to degrade fiber. Yet feeding a high-concentrate diet with coarsely chopped hay caused a depression of the in situ fibrolytic capacity of digesta in the reticulorumen, even though the amylolytic activity and total tract digestibility were not affected.

The lower in situ hay DM degradability for cows fed the HL diet in this study could also be (partly) attributed to the decline of ruminal $\mathrm{pH}$ of 5.5 at $2200 \mathrm{~h}$, which may have adversely affected the activity of fibrolytic microorganisms of the digesta. The $\mathrm{pH}$ in the rumen is a key determinant of ruminal digestion. Hoover (1986) proposed that a reduction in ruminal $\mathrm{pH}$ below 6.2 that was cyclic and of short duration could cause a moderate, transient reduction in fiber digestion. Furthermore, de Veth and Kolver (2001) reported that even a 4-h period of suboptimal $\mathrm{pH}$ (5.4) was critical for fiber digestion and would reduce the NDF degradability by about $4 \%$ in continuous culture. In the present study, the proportion of ruminal cellulolytic cocci (Ruminococcus albus, Ruminococcus flavefaciens, and Fibrobacter succino- 
genes), measured $1 \mathrm{~h}$ before and $3 \mathrm{~h}$ after the morning feeding, decreased in the fluid and particularly in the solid phase of the rumen as the dietary concentrate level increased (Ölschläger et al., 2006). Furthermore, the lower in situ hay DM degradability was also reflected in the low NDF degradation of hay when incubated in vitro with inoculum prepared with ruminal digesta collected by cows fed the HL diet (Zebeli et al., 2004).

\section{Particle Comminution, Ruminal Mat Characteristics, and Passage}

A longer time spent in rumination per unit of long fiber ingested leads to the assumption that the contribution of rumen microbial degradation to fiber breakdown was lowered. McLeod and Minson (1988) reported that mastication contributes about $80 \%$ to the particle breakdown, whereas the rest is generally attributed to microbial degradation. However, Tafaj et al. (2005a) discussed that ruminants try to compensate for a low microbial fiber breakdown in the reticulorumen by increasing the physical breakdown, which in turn extends the ruminating index. Results of this study support this hypothesis. A longer time spent ruminating per unit of $\mathrm{DM}_{>1.18 \mathrm{~mm}}$ for cows fed the HL diet was associated with low in situ hay DM and vitro NDF degradability, as well as with a higher proportion of large particles of ruminal digesta, which in turn all indicate lower microbial fiber breakdown in the reticulorumen.

Given that the Yb-NDF was ground, one cannot completely exclude the idea that this marker may have better represented the turnover of diets based on fine hay than those based on coarsely chopped hay. Therefore, the ruminal passage rates of solids for the HL diet, and particularly the LL diet, are probably somewhat overestimated. The retention time in the reticulorumen of solid digesta was the shortest for the HL diet and the longest for the LL diet, whereas the retention time in the lower digestive tract increased for the HL diet. This result suggests that for this treatment, fiber digestion shifted from the reticulorumen to the hindgut. Boddugari et al. (2001) reported that when the level of a fiber-rich concentrate $(40.3 \% \mathrm{NDF}$ in $\mathrm{DM})$ was increased from 62 to $70 \%$ in the diet of dairy cows, a significantly reduced digesta consistency in the reticulorumen was associated with a lowered entrapment of small particles, and hence an increased outflow rate of solid digesta and depressed ruminal NDF digestibility. In the present study, the ruminal mat consistency tended to improve, especially during the daytime, but the outflow rate of solids from the reticulorumen increased when the HL diet was fed. Similarly, Weidner and Grant (1994) observed that increasing the ruminal mat consistency by including $20 \%$ of coarsely chopped alfalfa hay in the ration was not sufficient to significantly reduce the rate of escape of soybean hulls from the rumen.

In addition, cows fed high-concentrate diets showed a lower percentage of small particles in the ruminal digesta when measured $3 \mathrm{~h}$ after the morning feeding, even though this particle fraction in the diet was higher compared with the low-concentrate diets; this in turn suggests less entrapment of small, potentially digestible feed particles. Sutherland (1988) postulated that the ruminal mat can modulate the retention time of solid digesta through an increased selective retention ("filter bed" effect) for undigested small feed particles. This likely affects more concentrate grains and especially small hay particles, which, if not integrated into the ruminal mat, have a greater probability of sedimenting because of the higher density, and consequently to flow out undigested from the reticulorumen (Zebeli et al., 2005). Poppi et al. (2001) concluded that small particles generated within the mat have difficulty escaping, but once in the ventral rumen pool, they escape quickly with a low probability of return to the mat. A lower mat-to-nonmat ratio and a higher bailable fraction, the latter comprising both liquids and small hay and grain particles, also support the hypothesis of a lower integration of small particles into the mat for the high-concentrate diets in this study. In addition, this result suggests that not only the consistency of the ruminal mat, but also the proportion of mat (i.e., mat-tononmat ratio) is important in regulating small particle retention in the rumen through selective retention.

Tafaj et al. (2005a) concluded that the procedure of feeding a coarsely chopped, fiber-rich hay (62\% NDF) to balance a high inclusion of concentrate $(50 \%)$ was not effective in overcoming the deficiency in physical fiber of the ration in dairy cows, because it did not improve rumen conditions for fiber degradation, even though ruminating indices increased. The attainment and maintenance of stable digesta stratification depends not only on the amount of dietary structural carbohydrates, but also on the degradation characteristics and extent of degradation of structural carbohydrates of the rumen mat itself (Welch, 1982). This in turn stimulates the backflow of potentially degradable particles from the ventral reticulorumen to the mat (Poppi et al., 2001), and hence may further enhance cellulolytic activity and fiber degradation in the rumen. Indeed, when higher quality hay (47\% NDF) was fed at a low concentrate level (20\%), Tafaj et al. (2005a) reported not only a better stratification of digesta in the reticulorumen and higher $\mathrm{pH}$, but also a higher fiber degradation, increased turnover rate of digesta, and increased hay intake without compromising effectiveness at stim- 
ulating chewing. The authors also justified the latter combination of dietary factors with a better dietary nutrient balance available for microorganisms, especially in terms of ruminally fermentable fiber and ammonia, which can stimulate the metabolic activity of cellulolytic microflora (Thomas and Russell, 2004), and hence fiber degradation in the rumen. An additional reason for the lower fibrolytic activity of ruminal digesta in cows fed the HL diet was presumably also the lack of synchronized nutrient availability, because of a lower integration of small grain and hay particles into the ruminal mat. Weimer (1998) noted that the concentration of fiber-degrading bacteria in the rumen is usually much greater than the concentration required to digest fiber, suggesting that metabolic activity rather than total count is pivotal in digesting fiber in the rumen. However, further research, both in terms of the rumen ecosystem and the metabolic activity of cellulolytic microorganisms in the rumen, is needed to elucidate the hypothesis that arose in the present study.

\section{CONCLUSIONS}

Altering the theoretical particle size of hay from 6 to $30 \mathrm{~mm}$ in a diet containing a high amount of concentrate increased the proportion of DM in the diet retained on a $1.18-\mathrm{mm}$ screen (wet-sieving) by $4.5 \%$, extended the rumination time by $100 \mathrm{~min} / \mathrm{d}$, and extended the ruminating index by about $13 \mathrm{~min} / \mathrm{kg}$ of $\mathrm{DM}_{>1.18 \mathrm{~mm}}$ ingested, and also increased the consistency of the ruminal mat. However, the ruminal particle breakdown, fibrolytic capacity of the digesta, entrapment of small particles into the mat, and proportion of mat in the rumen decreased. This was also reflected in a higher bailable liquid pool, increased fractional passage rate of solid digesta from the reticulorumen, and increased retention time in the hindgut, which in turn indicated a shift of fiber digestion from the rumen to the lower digestive tract. It can be concluded, based on the results of this study, that inclusion of coarsely chopped hay in the high-concentrate diet does not appear to further improve rumen conditions and digestion when the rations are formulated to exceed the fiber requirements in limit-fed dairy cows.

\section{ACKNOWLEDGMENTS}

The study was funded by a grant from the German Research Foundation (DFG, code no. DR 92/11-1). The assistance of B. Junck, V. Ölschläger, and H. Ott in this research is highly appreciated. We thank the staff of the experimental unit of the Institute of Animal Nutrition for their help during the sampling and the staff of technical unit of the University of Hohenheim for assistance in developing the apparatus to measure the ruminal mat consistency. We would also like to thank the 2 anonymous reviewers for their valuable suggestions.

\section{REFERENCES}

Allen, M. S. 1997. Relationship between fermentation acid production in the rumen and the requirement for physically effective fiber. J. Dairy Sci. 80:1447-1462.

Beauchemin, K. A., and L. M. Rode. 1997. Minimum versus optimum concentrations of fiber in dairy cow diets based on barley silage and concentrates of barley or corn. J. Dairy Sci. 80:1629-1639.

Beauchemin, K. A., W. Z. Yang, and L. M. Rode. 2003. Effects of particle size of alfalfa-based dairy cow diets on chewing activity, rumen fermentation, and milk production. J. Dairy Sci. 86:630-643.

Boddugari, K., R. J. Grant, R. Stock, and M. Lewis. 2001. Maximal replacement of forage and concentrate with a new wet corn milling product for lactating dairy cows. J. Dairy Sci. 84:873-884.

Cherney, D. J. R., J. A. Paterson, and R. P. Lemenager. 1990. Influence of in situ bag rinsing technique on determination of dry matter disappearance. J. Dairy Sci. 73:391-397.

de Veth, M. J., and E. S. Kolver. 2001. Diurnal variation in $\mathrm{pH}$ reduces digestion and microbial protein when pasture is fermented in continuous culture. J. Dairy Sci. 84:2066-2072.

Dijkstra, J., J. A. N. Mills, and J. France. 2002. The role of dynamic modelling in understanding the microbial contribution to rumen function. Nutr. Res. Rev. 15:67-90.

Firkins, J. L., M. L. Eastridge, N. R. St-Pierre, and S. M. Noftsger. 2001. Effects of grain variability and processing on starch utilization by lactating dairy cattle. J. Dairy Sci. 79(E Suppl.):E218E238.

Fisher, D. S., J. C. Burns, and K. R. Pond. 1988. Estimation of mean particle size of ruminant digesta. J. Dairy Sci. 71:518-524.

GfE (Gesellschaft für Ernährungsphysiologie). 2001. Empfehlungen zur Energie- und Nährstoffversorgung der Milchkühe und Aufzuchtsrinder. Nr. 8. DLG Verlag, Frankfurt am Main, Germany.

Hoover, W. H. 1986. Chemical factors involved in ruminal fiber digestion. J. Dairy Sci. 69:2755-2767.

Kononoff, P. J., and A. J. Heinrichs. 2003. The effect of reducing alfalfa haylage particle size on cows in early lactation. J. Dairy Sci. 86:1445-1457.

Mambrini, M., and J. L. Peyrand. 1997. Retention time of feed particles and liquids in the stomachs and intestines of dairy cows: Direct measurement and calculations based on faecal collection. Reprod. Nutr. Dev. 37:427-442.

McDonald, I. 1981. A revised model for the estimation of protein degradability in the rumen. J. Agric. Sci. 96:251-252.

McLeod, M. N., and D. J. Minson. 1988. Large particle breakdown by cattle eating ryegrass and alfalfa. J. Anim. Sci. 66:992-999.

Mertens, D. R. 1997. Creating a system for meeting the fiber requirements of dairy cows. J. Dairy Sci. 80:1463-1481.

Moore, J. A., K. R. Pond, M. H. Poore, and T. G. Goodwin. 1992. Influence of model and marker on digesta kinetic estimates for sheep. J. Anim. Sci. 70:3528-3540.

Naumann, K., and R. Basler. 1997. VDLUFA-Methodenbuch (1976). Band III. Die chemische Untersuchung von Futtermitteln. Ergänzungslieferungen von 1983, 1988, 1993, 1997. VDLUFA-Verlag, Darmstadt, Germany.

NRC. 2001. Nutrient Requirements of Dairy Cattle. 7th rev. ed. Natl. Acad. Sci., Washington, DC.

Ölschläger, V., I. Weber, W. Vahjen, M. Tafaj, O. Simon, and W. Drochner. 2006. Effect of hay particle size and concentrate level on the main cellulolytic bacteria in the rumen of dairy cows. Proc. Soc. Nutr. Physiol. 15:147. (Abstr.)

Poppi, D. P., W. C. Ellis, J. H. Matis, and C. E. Lascano. 2001. Marker concentration patterns of labelled leaf and stem particles in the rumen of cattle grazing Bermuda grass (Cynodon dactylon) analysed by reference to a raft model. Br. J. Nutr. 85:553-563. 
Robinson, P. H., S. Tamminga, and A. M. van Vuuren. 1987. Influence of declining level of feed intake and varying the proportion of starch in the concentrate on rumen ingesta quantity, composition and kinetics of ingesta turnover in dairy cows. Livest. Prod. Sci. 17:37-62.

SAS Institute. 2001. SAS User's Guide: Statistics. Release 8.2. SAS Inst. Inc., Cary, NC.

Sudweeks, E. M., L. O. Ely, D. R. Mertens, and L. R. Sisk. 1981. Assessing minimum amounts and form of roughage in ruminant diets: Roughage value index system. J. Anim. Sci. 53:1406-1411.

Sutherland, T. M. 1988. Particle separation in the forestomachs of sheep. Pages 43-73 in Aspects of Digestive Physiology in Ruminants. A. Dobson, and M. J. Dobson, ed. Cornell Univ. Press, Ithaca, NY.

Tafaj, M., V. Kolaneci, B. Junck, A. Maulbetsch, H. Steingass, and W. Drochner. 2005a. Influence of fiber content and carbohydrate level on chewing activity, ruminal digestion, digesta passage rate and nutrient digestibility in dairy cows in late lactation. Asianaustralas. J. Anim. Sci. 18:1116-1124.

Tafaj, M., Q. Zebeli, B. Junck, H. Steingass, and W. Drochner. 2005b. Effects of particle size of a total mixed ration on in vivo ruminal fermentation patterns and inocula characteristics used for in vitro gas production. Anim. Feed Sci. Technol. 123-123:139-154.

Thomas, S., and J. B. Russell. 2004. The effect of cellobiose, glucose, and cellulose on the survival of fibrobacter succinogenes A3C cultures grown under ammonia limitation. Curr. Microbiol. 48:219-223.

Uden, P., P. E. Colucci, and P. J. van Soest. 1980. Investigation of chromium, cerium and cobalt as digesta markers in rate of passage studies. J. Sci. Food Agric. 31:625-632.
Van Soest, P. J., J. B. Robertson, and B. A. Lewis. 1991. Methods for dietary fiber, neutral detergent fiber and non-starch polysacharide in relation to animal nutrition. J. Dairy Sci. 74:35833597.

Weidner, S. J., and R. J. Grant. 1994. Altered ruminal mat consistency by high percentages of soyabean hulls to lactating cows. J. Dairy Sci. 77:522-532.

Weimer, P. J. 1998. Manipulating ruminal fermentation: A microbial ecological perspective. J. Anim. Sci. 76:3114-3122.

Welch, G. J. 1982. Rumination, particle size, and passage from the rumen. J. Anim. Sci. 54:885-894.

Yang, W. Z., and K. A. Beauchemin. 2006. Effects of physically effective fiber on chewing activity and ruminal $\mathrm{pH}$ of dairy cows fed diets based on barley silage. J. Dairy Sci. 89:217-228.

Yang, W. Z., K. A. Beauchemin, and L. M. Rode. 2001. Barley processing, forage: Concentrate ratio, and forage length effects on chewing and digesta passage in lactating dairy cows. J. Dairy Sci. 84:2709-2720.

Zebeli, Q., M. Tafaj, and W. Drochner. 2004. Einfluss der Partikellänge von Heu und des Kraftfutterniveaus in der Ration auf in vitro Verdauungscharakteristika des Panseninhaltes bei Milchkühen (Effect of forage particle size and concentrate level in the diet on in vitro digestive characteristics of ruminal digesta in dairy cows). Page 157 in Proc. 116th VDLUFA Congress, Rostock, Germany. (Abstr.) VDLUFA Verlag, Darmstadt, Germany.

Zebeli, Q., M. Tafaj, B. Junck, and W. Drochner. 2005. Effect of hay particle size and concentrate level on ruminal mat characteristics in dairy cows. Proc. Soc. Nutr. Physiol. 14:120. (Abstr.)

Zebeli, Q., M. Tafaj, H. Steingass, B. Metzler, and W. Drochner. 2006. Effects of physically effective fiber on digestive processes and milk fat content in early lactating dairy cows fed total mixed rations. J. Dairy Sci. 89:651-668. 